\title{
Fire in the Forest: Public Perceptions of Ecological Restoration in North-central Arizona
}

\author{
David M. Ostergren, Jesse B. Abrams and Kimberly A. Lowe
}

\begin{abstract}
In recent years residents of the intermontane West have experienced a series of expensive and high-profile fire seasons. One result is that the concept of ecological restoration has moved squarely into public view. As scientists and practitioners continue to refine the definition of ecological restoration as a practical matter, citizens are forming their own perceptions of how restoration should be applied to local forests. We used a recent public opinion survey in north-central Arizona to assess public views of restoration. Our findings indicate broad support for restoration although portions of the population, particularly those in rural areas, see restoration primarily as a means to protect human lives and property from fire. Most importantly, our findings suggest that a majority of the public in this region have a view of restoration beyond fire risk reduction, but vary in their willingness to accept dramatic changes to forest conditions.
\end{abstract}

Keywords: Arizona, fire, ponderosa pine (Pinus ponderosa), public opinion, restoration

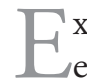
xtensive crown fires in southwestern United States forests over the last decade, such as the 2000 Cerro Grande fire in New Mexico and the 2002 Rodeo-Chediski burn in Arizona, have precipitated federal policy changes that emphasize preemptive forest treatments in addition to traditional fire suppression activities. In 2000, for example, an interagency report to the president emphasized the importance of "reducing hazardous fuel accumulations in our forests and rangelands and restoring the health and natural processes of forest and rangeland ecosystems" (USDA/ DOI 2000, 14). The 2000 National Fire Plan emphasizes fuels reduction and restoring fire to forest ecosystems (National Fire Plan 2001). A primary purpose of the Healthy Forest Restoration Act (HFRA) is "to reduce wildfire risk to communities, municipal water supplies, and other at-risk Federal land through a collaborative process of planning, prioritizing, and

Ecological Restoration Vol. 26, No. 1, 2008 ISSN 1522-4740 E-ISSN 1543-4079 (C)2008 by the Board of Regents of the University of Wisconsin System. implementing hazardous fuel reduction projects” (HFRA 2003, \$2501). These policies institutionalize a new direction for the management of forests on public lands and have placed forest restoration squarely within public view.

A wide spectrum of managers, policy makers, nongovernment organizations and members of the public agree that restoration efforts are needed to produce "healthier" or "more natural" conditions on public lands. There is wide debate, however, about specific parameters and processes of restoration (e.g., Jordan 2000, Katz 2000). In addition, planning for restoration on public lands means involving a wide array of participants with divergent, often competing, agendas. Key components to planning include the 1969 National Environmental Policy Act process and new strategies that involve the public to a greater degree, such as collaborative planning (Brick et al. 2001), adaptive governance (Brunner et al. 2005), and participatory landscape analysis (Sisk et al. 2006). The process is often slow, as these issues are ecologically complex and contain a high degree of uncertainty (Joyce
2003). While these strategies place a high premium on public participation, forest restoration can have different meanings for different individuals. In this article, we share the results of a self-administered mail survey completed in 2001 that aimed to assess how residents of the southwestern U.S. view forest restoration.

\section{A Continuum of Restoration}

Southwestern forests have received a great deal of attention from restoration researchers and practitioners (Schumman 2004). Timber harvesting, overgrazing, and fire suppression after Euro-American settlement changed ecosystem structure, composition, and processes with the result that ponderosa pine (Pinus ponderosa) forests are generally described as degraded and out of their natural range of variability (Cooper 1960, Covington et al. 1994, Covington 2003a, Kaufmann et al. 2004, Moore et al. 2004). Some authors emphasize the urgency of declining forest health in the southwest and call for swift remedial action to restore ecological health before 
more acres are lost to uncharacteristic and devastating crown fire (Covington 2000).

Confounding this call to action, the social landscape of ponderosa pine restoration is characterized by discord and disagreement (Friederici 2003, Burns 2003, Moote 2003). Approaches to restoration treatments are diverse and sometimes conflicting, but can be understood to fall on a kind of continuum. Noss et al. describe restoration as "guiding an ecosystem along a trajectory of recovery of natural structure, function, and composition, that is, toward ecological health and integrity" (2006, 7). A strict interpretation of restoration incorporates principles of ecological fidelity to bring degraded forests back in line with historic trajectories on large spatial and temporal scales (Covington 2003b, Friederici 2003). One model attempts to recreate forest structure using historic evidence (e.g., stumps, holes) as a guide for restoring clumps of trees, openings, and individual trees in a given stand (Mast et al. 1999, Moore et al. 1999, Friederici 2005). This approach might recommend an aggressive thinning program to reduce a 3,000 stems/ha density to 150 stems/ ha and then reintroduce fire. Allen et al. (2002) advocate slower, more incremental change that preserves existing patterns of larger trees, rather than attempting to restore exact predegradation patterns. While there are some important differences between these two models, they both advocate a mixture of mechanical interventions and low-intensity fire reintroduction (i.e., Wildland Fire Use).

Restoration as "fire risk reduction," on the other hand, has the primary goal of altering fire behavior via changing fuel loads, and does not emphasize ecological patterns and processes (Allen et al. 2002). This form of forest restoration is increasingly common in close proximity to communities and homes.

Another approach to forest restoration is the "natural regulation paradigm," which has received a great deal of criticism (Bonnicksen 1994, Agee 2002, Thomas 2002). Under this "hands-off" paradigm, nature is selfregulating and should be allowed to take its course unimpeded by human actions (Bonnicksen 1994). Advocates view crown fires, for example, as a first step toward the forest healing itself because they leave a mosaic of forest conditions. Significant portions of the public appear to be sympathetic to a passive management strategy (Winter and Cvetkovich 2003, Shindler et al. 2002, Brunson and Shindler 2004).

This review indicates the broad social context of restoration as well as the fundamental questions that remain about what to restore to, when to restore, and how much intervention is good without being too much (for further discussion see Gobster and Hull 2000, Gross 2003, Allison 2004, Simpson 2005). With our mail survey, we sought to shed light on residents' opinions and perceptions of restoration. This area is at a high risk for large fires, and residents have heard a variety of messages about forest restoration from the news media, nonprofit groups, the U.S. Forest Service (USFS), and the Ecological Restoration Institute at Northern Arizona University as well as state and municipal agencies. A review of National Forest web sites in north-central Arizona, for example, reveals that the USFS is very careful to describe its activities as hazardous fuels treatment and not restoration. Nonetheless some of the hottest news stories reported on forest restoration, come from the USFS and multiple interest groups (Arizona Daily Sun 2001). The Greater Flagstaff Forests Partnership (www.gffp.org), for example, is a collaborative multistakeholder effort with multiple missions, one of which is outreach and education on forest restoration.

\section{Literature on the Public View}

Public knowledge and perception of any management action influences the debate and acceptance or rejection of that action. Several years after the 1988 wildfires in Yellowstone National Park, for example, public outcry caused all federal land management agencies to dramatically reduce the number of lightning-ignited fires they allowed to burn. Since then, land management agencies have slowly increased the number of fires allowed to burn, however, as the positive results from the Yellowstone fires emerge.

Common elements of southwestern forest restoration include prescribed fire, mechanical thinning, and manipulating plant and animal populations to favor native species and reduce the presence of nonnative species. These elements may be applied in isolation or in combination. They may also be included in management actions that are not restoration projects. Even regarding something as apparently as straightforward as treating excessively dense, small-diameter stands of pine, however, public attitudes can vary widely_the result of "a diverse set of individual experiences, connections to the forest, knowledge sources, cultural influences, and fundamental values" (Findley et al. 2001, 24). Definitions of restoration are informed by individual understandings of "naturalness" (Vining et al. 2000, Bright et al. 2002), perceptions of science (Helford 2000, Woolley and McGinnis 2000), as well as emotional attachments to a landscape (Vining et al. 2000, Findley et al. 2001, Graber 2003).

\section{Prescribed fire}

Fire is a keystone ecological process in southwestern forests and is often the most visible element to the public. Indeed, the redefinition of some fire as "good" is the most dramatic change in forest policy since 1910 (Pyne 2004). Changes in attitude toward prescribed fire have been examined extensively as it has become more common. Trends show an increase in public acceptance and understanding of prescribed fire (Shelby and Speaker 1990, Loomis et al. 2001). However, positive attitudes toward prescribed fire are far from universal. Public acceptance of the practice appears to be influenced by a number 
of factors, including the extent of people's knowledge about prescribed fire (Taylor and Daniel 1984, Manfredo et al. 1990, Loomis et al. 2001), the level of trust in the agency implementing the practice (Winter et al. 2002, Winter et al. 2004, Vogt et al. 2003), and beliefs regarding the ultimate outcomes (Manfredo et al. 1990, Winter and Fried 2000). As knowledge, trust, and a belief in the outcome increase, so does acceptance. Demographic factors such as age, income, gender, location, and education also influence acceptance of prescribed fire and smoke (Manfredo et al. 1990, Shindler et al. 2002, Winter and Cvetkovich 2003, Brunson and Shindler 2004, Ostergren et al. 2006). In addition, a study in Utah revealed that prescribed fire and whether managers can use it "wherever managers see fit" loses some its acceptance if the fire escapes, but the general support for prescribed fire remained high enough to continue its use (Brunson and Evans 2005).

\section{Mechanical thinning}

Like prescribed fire, mechanical thinning is both a means of reducing wildland fuels and a tool for achieving restoration. Thinning tends to be publicly supported, but issues of agency credibility and trust are important determinants of acceptance (Vogt et al. 2003, Winter et al. 2004). Some view thinning simply as commercial logging in disguise (Findley et al. 2001). In some western forest cases, survey respondents showed greater support for thinning than prescribed fire (Shindler et al. 2002, Vogt et al. 2003, Brunson and Shindler 2004, Brunson and Evans 2005). However Toman and Shindler (2003) found that northeast Oregon residents solidly preferred thinning followed by prescribed fire over either one in isolation or no management at all.

Attitudes toward mechanical thinning vary across personal experience and environmental value orientations (Vogt et al. 2003, Abrams et al. 2005). Brunson and Shindler (2004) found significant differences in support for mechanical thinning between Arizona, Colorado, Oregon, and Utah. Shindler et al. (2002) found that very large majorities of urban and rural residents in the Pacific Northwest believed mechanical thinning was appropriate for "overstocked forests," but significant differences were found in their approval under "depleted" and "healthy" conditions. Vogt (2003) found no significant differences in acceptance of mechanical fuel reduction between seasonal and permanent home owners in California, Colorado, and Florida. Mechanical fuel reduction seems to be best supported when the goals of the project are clear and related to improving forest health.

\section{Manipulating plant and animal species}

A third element in ecological restoration is species composition and either extirpating invasives or reintroducing native species. The literature is relatively scant on public perception of species manipulation in southwestern forests. In a national survey for the National Park Service, Solop et al. (2004) found the public evenly split on species eradication or reintroduction. More educated and higher income respondents were more likely to favor removal of nonnative species. Meadow et al. (2005) examined changing attitudes of people in Arizona, Colorado, and New Mexico toward restoration of the gray wolf (Canis lupus). They found 64\% of all respondents favored reestablishing wolves and $33 \%$ opposed, although more than half of all rancher respondents did not favor wolf restoration.

\section{Passive management}

Several recent studies have addressed public perceptions of "passive management." In a 2001-2002 survey, 7.5\% of southwest resident respondents (ranging from $5.4 \%$ of Californians to $10.5 \%$ of New Mexicans) felt that fires should be allowed to "take their natural course when burning in wildland or wilderness areas, even if structures are involved" (Winter and Cvetkovich
2003). Fewer than $10 \%$ of Oregon and Washington resident respondents felt that this was an appropriate course of action even for overstocked forests (Shindler et al. 2002). However, 42\% of urban respondents and $32 \%$ of rural respondents believed "letting nature take its course" was appropriate management for healthy forests. Nearly half (48\%) of respondents in four western states agreed that "following nature's way is preferable to intervention in ecosystems" (Brunson and Shindler 2004). Natural regulation is a valueladen phrase, and its acceptability may depend on whether the public believes that the forest is in a "natural" state, that is, whether people judge the forest to be healthy or normal.

These survey results indicate that residents of these areas are aware of forest management practices and have definite opinions on the various elements of specific actions that may be entailed in forest restoration. But do residents understand that each action, or combination of actions, has qualitative implications for forest health and restoration? Mechanical thinning alone in a ponderosa pine ecosystem would not have the same restorative effect on function, composition, and process as would a comprehensive strategy of density reduction, species reintroduction, and eradication, and the reestablishment of the historic fire regime (regardless of whether these ends are met through mechanical or non-mechanical means).

While the scientific literature is replete with detailed descriptions of what "good" ecological restoration is (Jackson et al. 1995, Hobbs and Norton 1996, Higgs 1997), no previous studies have tried to assess the public perception of restoration in southwestern ponderosa pine forests. Fighting fire and forest conditions in general are salient issues for residents in north-central Arizona. Before our survey, we expected the public to be aware of fuel reduction strategies but did not expect a majority of the public to have a deeper understanding and support of restoration. 


\section{Surveying North-Central Arizona Residents}

As part of a research project funded by the Ecological Research Institute at Northern Arizona University, we administered a mail survey to regional residents in 2003. Questions on the survey were split between people's perceptions of forest restoration and mountain lion policy. Our target population was adult ( $>18$ years old) seasonal or permanent residents who have lived in the area one year or longer. We selected our independent variables based on current literature of fire perceptions and policy acceptance (Brunson et al. 1997, Shindler et al. 1993, Cortner et al. 2003). Complete details on the survey format and methodology are available from the authors.

Thirty-five zip codes in the sample area were determined by laying a zip code map over a vegetation map of Arizona. The area surveyed starts at the Utah border and north rim of Grand Canyon National Park and stretches southeast through the largest urban area of Flagstaff (population 60,000) along the Mogollon Rim and the Fort Apache Reservation to the New Mexico border, with an "island" that includes Prescott (Figure 1). In 2003 we sent four mailings to 1,644 U.S. Postal Service-approved addresses. Our initial mailing was a pre-notice letter (Dillman 2000). Forty-six percent (750) of the questionnaires were returned. Fifty-seven of the questionnaires were unusable, for a total sample size of 693. This return rate is consistent with other natural resourcefocused mail survey return rates (Connelly et al. 2003).

Respondents were mostly white males, aged 45-65 years and comparatively well-educated. Eighty-eight percent of the respondents reported their ethnicity as Caucasian. U.S. Census Bureau (Census) data for Coconino County indicates that only $77 \%$ of residents are Caucasian. The sample underrepresents Native Americans (1.2\% vs. $10 \%)$ and Hispanics (4\%

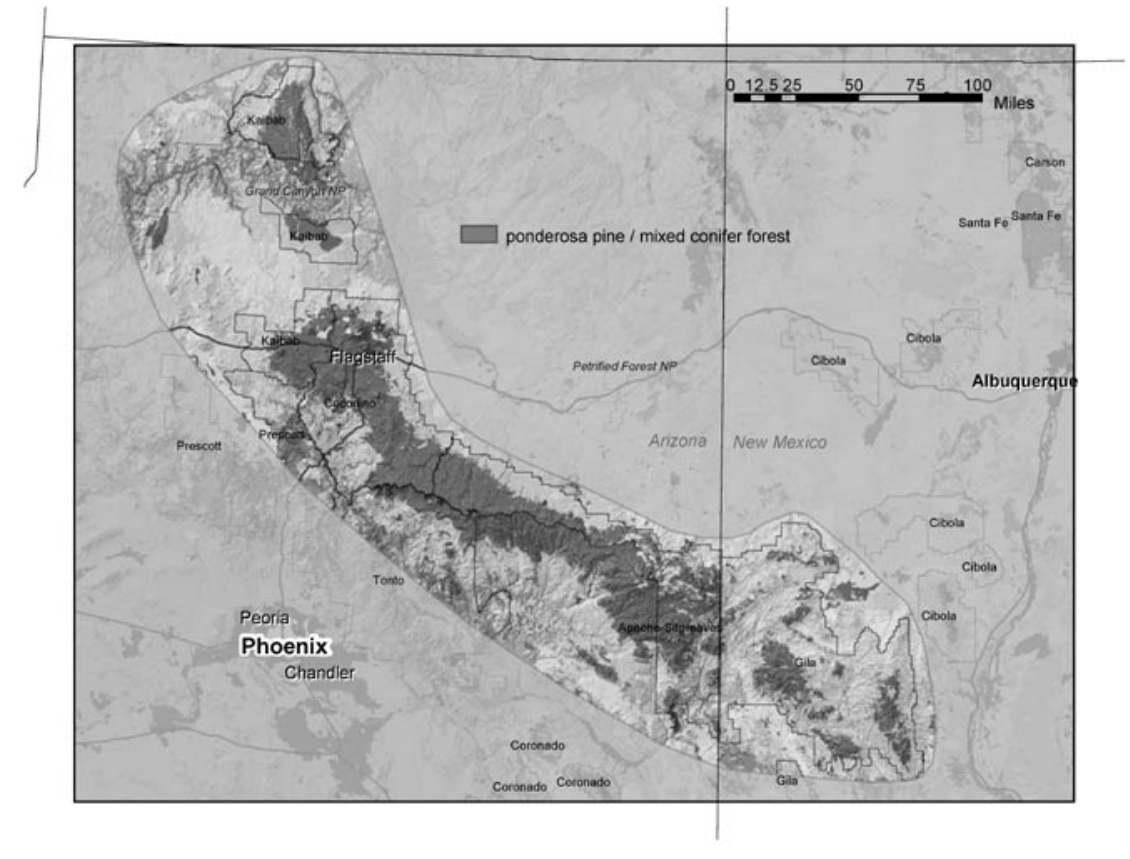

Figure 1. Map depicting survey area (outlined) and extent of ponderosa pine (Pinus ponderosa) ecosystems (dark shading) in north-central Arizona. Reprinted with permission from Forest Ecosystem Restoration Analysis (www.forestera.nau.edu/data_overview.htm).

vs. $10.9 \%$ ), and we do not draw any conclusions based on ethnicity. Mean respondent age was 57.8 years old $(n=$ $676, S D=14.33$ ), with age ranging from 19 to 93 . This age range does not match Census Bureau 2000 statistics but is consistent with a voting population, the group we assumed would participate in decision making (Theodori and Luloff 2002). Ninetyone percent of respondents were permanent residents. Sixty-eight percent were male and 32 percent female, which is skewed from an even gender ratio reported by the 2000 Census. A plurality of the respondents reported an income of $\$ 30,000$ to $\$ 59,999$ $(38 \%)$. Sixty percent of respondents reported living in rural areas, while $39.9 \%$ reported living in an urban area (i.e., Flagstaff).

\section{Survey Results}

\section{Management activities}

Respondents were asked what activities they believed were included in forest restoration from a list of choices that included "thinning of trees," "removing nonnative plant and animal species," "prescribed burns," "planting native species," and "native plant and animal species preservation." Respondents could select more than one activity. A large majority (76.5\%) believed that restoration included $a t$ least the two activities of thinning and prescribed burning (Table 1). A key question, however, is to what degree respondents believed restoration consists simply of thinning and burning, and to what degree they believe restoration goes further to include more "holistic" activities such as native species preservation and reintroduction or nonnative species control.

Just $16.5 \%$ of respondents believed forest restoration includes only thinning and prescribed burning and none of the other activities. A full $60 \%$ of all survey respondents agreed that forest restoration includes thinning, prescribed burning, and at least one more action. About 30\% selected nonnative species removal, and roughly half selected native species planting or native species preservation. The remainder $(23.5 \%)$ did not choose both thinning and burning, but may have selected thinning without choosing burning $(7.1 \%)$, burning but not 
Table 1. Percentage of total responses that were positive to the survey question "Which of the following do you believe is included in forest restoration? Please check all that apply." Respondents are north-central Arizona residents $(n=686)$.

\begin{tabular}{lc}
\hline Management Activity & $\%$ Yes \\
\hline At least thinning and burning & 76.5 \\
Thin + burn + species preservation & 50.4 \\
Thin + burn + planting native species & 46.4 \\
Thin + burn + removing non-native species & 29.9 \\
Thinning and burning only & 16.5 \\
Burning but not thinning & 11.7 \\
Thinning but not burning & 7.1 \\
Neither thinning nor burning & 4.7 \\
\hline
\end{tabular}

thinning (11.7\%), or neither thinning nor burning $(4.7 \%)$.

\section{Purpose of restoration}

A second series of questions aimed to identify how residents perceived the purpose of restoration and their opinion on some of the more concrete results of restoration (Tables 2 and 3). Table 2 shows percentages of respondents answering survey questions according to education level and residential location. Table 3 provides chi-square comparisons of respondents according to education level and area of residence.

In general, this public supports restoration. Eighty-one percent believe restoration is important because "they like forests." Respondents with high school education were more likely to agree with this statement than those with some college or graduate education. An even larger majority, 84.3\%, support restoration because they agree "it is our duty to care for the natural world." We anticipated that the 200,000-ha Rodeo-Chediski fire in 2002 would bias residents to believe that the purpose of restoration is primarily to protect humans from fire. However only $31.7 \%$ agreed with this statement and 50.1\% disagreed. The chi-square results reveal that people who completed high school were more likely to agree with this statement than people with some college or graduate education. Urban residents were more likely to disagree with this statement than rural residents.
In terms of the purpose of restoration, a large majority, $87.1 \%$, of respondents agreed that the main purpose of forest restoration should be to promote working ecosystems. People with some college or graduate school education were more likely to agree with this statement than people who only completed high school. Urban residents were more likely to agree with this statement than rural residents. When we designed the question we intended "working ecosystems" to be synonymous with "functioning" or "natural ecosystems." However, a reasonable interpretation by respondents could have been that a "working ecosystem" is a commercially productive forest. A follow-up statement was that "forest restoration efforts should be used to help recover plant and animal species that are rare and endangered." Seventy-four (74.2) percent agreed with this statement. We interpret this to support our assumption that the term "working" means to function as an ecosystem. Urban residents were more likely to agree with this statement than rural residents.

In one strategy of restoration a significant portion of ponderosa pine trees are removed before fire is reintroduced. Respondents were split on this issue, with $38.7 \%$ agreeing with the statement "I would support forest restoration even if most trees, large and small, were removed" and $48.3 \%$ disagreeing. Rural respondents were more likely to disagree with this statement than urban respondents. Continuing this line of analysis we asked about removing large trees in general. One obstacle to implementing restoration plans is a debate over diameter caps. A 40-cm diameter cap (i.e., a prohibition on cutting trees over $40 \mathrm{~cm}$ in diameter at breast height) is often advocated by groups and individuals opposed to the removal of large trees during restoration efforts. Fiftyfive (55.2) percent of north-central Arizonan respondents disagreed with the statement that "large trees should never be removed in restoration efforts" and 30.5\% agreed. Though a majority accepts large tree removal, the minority has a strong political voice. For instance, an early ponderosa pine restoration effort in the Flagstaff region was amended to restrict cutting trees over $40 \mathrm{~cm}$ in diameter, despite the fact that large trees are not necessarily old trees and that, more importantly, the USFS and many researchers agree that some large trees need to be removed for structural restoration of an area (Ghiotto 2000, USFS 2000). Rural residents were more likely to disagree with this statement than urban residents.

We also sought to determine public perceptions of the ultimate management requirements of a restored forest. That is, does the public agree that the forest should be thinned only once and then allowed to go wild? A strong $61.5 \%$ disagreed with this approach, implying that the forest should not be allowed to "go wild." We infer that the public expects forest management activities to continue to shape ponderosa pine ecosystems into the future. Rural residents were more likely to disagree with this statement than urban residents. One potential confounding variable in this question is the term "wild." Our intention was that wild is synonymous with "natural" as in natural fire regimes, or hosting a full complement of plant and animal species. Wild, however, is not valueneutral and may be associated with congressionally designated wilderness, closed roads, or images of chaos and uncontrolled fires. 
Table 2. Responses to survey questions according to north-central Arizona respondents' education level and residential location. SA/A: Strongly agree and agree; N: Neutral; SD/D: Strongly disagree and disagree.

\begin{tabular}{|c|c|c|c|c|c|c|}
\hline \multirow[b]{2}{*}{ Question (number of respondents) } & \multirow[b]{2}{*}{ Response } & \multicolumn{3}{|c|}{ Education } & \multicolumn{2}{|c|}{ Urban/Rural } \\
\hline & & $\begin{array}{c}\text { Complete HS } \\
(\%)\end{array}$ & $\begin{array}{c}\text { Some College } \\
(\%)\end{array}$ & $\begin{array}{c}\text { Some Graduate } \\
\text { School (\%) }\end{array}$ & $\begin{array}{l}\text { Urban } \\
(\%)\end{array}$ & $\begin{array}{c}\text { Rural } \\
(\%)\end{array}$ \\
\hline \multirow{3}{*}{$\begin{array}{l}\text { I think forest restoration is important } \\
\text { because I like forests }(n=669)\end{array}$} & SA/A & 18.78 & 54.33 & 26.89 & 49.45 & 50.55 \\
\hline & Neutral & 17.78 & 47.78 & 34.44 & 52.22 & 47.78 \\
\hline & $\mathrm{SD} / \mathrm{D}$ & 17.14 & 34.29 & 48.57 & 42.86 & 57.14 \\
\hline \multirow{3}{*}{$\begin{array}{l}\text { We should restore our forests because it } \\
\text { is our duty to care for the natural world } \\
(n=680)\end{array}$} & SA/A & 18.91 & 51.67 & 29.42 & 48.87 & 51.13 \\
\hline & Neutral & 15.19 & 54.43 & 30.38 & 55.70 & 44.30 \\
\hline & $\mathrm{SD} / \mathrm{D}$ & 21.43 & 57.14 & 21.43 & 39.29 & 60.71 \\
\hline \multirow{3}{*}{$\begin{array}{l}\text { The main purpose of restoration is to } \\
\text { protect humans from fire }(n=685)\end{array}$} & $\mathrm{SA} / \mathrm{A}$ & 26.85 & 49.54 & 23.61 & 41.01 & 58.99 \\
\hline & Neutral & 15.32 & 54.03 & 30.65 & 51.20 & 48.80 \\
\hline & $S D / D$ & 14.58 & 53.06 & 32.36 & 53.94 & 46.06 \\
\hline \multirow{3}{*}{$\begin{array}{l}\text { The main purpose of forest restoration } \\
\text { should be to promote working } \\
\text { ecosystems }(n=675)\end{array}$} & SA/A & 16.38 & 53.58 & 30.04 & 51.70 & 48.30 \\
\hline & Neutral & 22.45 & 48.98 & 28.57 & 44.90 & 55.10 \\
\hline & $\mathrm{SD} / \mathrm{D}$ & 31.57 & 42.11 & 26.32 & 26.32 & 73.68 \\
\hline \multirow{3}{*}{$\begin{array}{l}\text { Forest restoration efforts should be used } \\
\text { to help recover plant and animal species } \\
\text { that are rare and endangered }(n=681)\end{array}$} & $\mathrm{SA} / \mathrm{A}$ & 18.69 & 49.70 & 31.61 & 53.27 & 46.73 \\
\hline & Neutral & 15.85 & 56.10 & 28.05 & 47.56 & 52.44 \\
\hline & $S D / D$ & 21.27 & 60.64 & 18.09 & 30.85 & 69.15 \\
\hline \multirow{3}{*}{$\begin{array}{l}\text { I would support forest restoration even } \\
\text { if most trees, large and small, were } \\
\text { removed }(n=683)\end{array}$} & $S A / A$ & 18.63 & 49.43 & 31.94 & 50.76 & 49.24 \\
\hline & Neutral & 15.73 & 46.07 & 38.20 & 60.67 & 39.33 \\
\hline & $S D / D$ & 19.15 & 56.53 & 24.32 & 45.45 & 54.55 \\
\hline \multirow{3}{*}{$\begin{array}{l}\text { Large trees should never be removed in } \\
\text { restoration efforts }(n=685)\end{array}$} & $\mathrm{SA} / \mathrm{A}$ & 15.38 & 48.56 & 36.06 & 53.59 & 46.41 \\
\hline & Neutral & 15.31 & 56.12 & 28.57 & 59.18 & 40.82 \\
\hline & $S D / D$ & 20.95 & 53.32 & 25.73 & 44.97 & 55.03 \\
\hline \multirow{3}{*}{$\begin{array}{l}\text { For restoration, the forest may be } \\
\text { thinned out by logging but only once } \\
\text { and then allowed to go wild }(n=686)\end{array}$} & $S A / A$ & 16.67 & 49.16 & 34.17 & 51.24 & 48.76 \\
\hline & Neutral & 15.38 & 55.25 & 29.37 & 59.44 & 40.56 \\
\hline & $S D / D$ & 20.43 & 52.25 & 27.32 & 45.50 & 54.50 \\
\hline \multirow{3}{*}{$\begin{array}{l}\text { We should allow natural areas to evolve } \\
\text { as they will without any intervention } \\
(n=683)\end{array}$} & SA/A & 25.21 & 44.02 & 30.77 & 52.54 & 47.46 \\
\hline & Neutral & 15.00 & 59.00 & 26.00 & 49.00 & 51.00 \\
\hline & $\mathrm{SD} / \mathrm{D}$ & 14.99 & 55.90 & 29.11 & 47.55 & 52.45 \\
\hline \multirow{3}{*}{$\begin{array}{l}\text { Restoration efforts will help control } \\
\text { nature }(n=676)\end{array}$} & $\mathrm{SA} / \mathrm{A}$ & 21.15 & 55.89 & 22.96 & 40.84 & 59.16 \\
\hline & Neutral & 17.89 & 54.30 & 27.81 & 53.64 & 46.36 \\
\hline & $S D / D$ & 13.02 & 44.79 & 42.19 & 60.42 & 39.58 \\
\hline
\end{tabular}

A follow-up statement sheds light on the issue: "we should allow natural areas to evolve as they will without any intervention.” Fifty (50.8) percent of north-central Arizonans surveyed disagreed with this statement and $34.6 \%$ agreed. Slightly more than half of north-central Arizona respondents agreed that the forest should not be left unmanaged. People who completed high school were more likely to agree with this statement than people with some college or graduate school education. At the same time, nearly half $(49.3 \%)$ of residents believed that restoration will help us "control nature," while $28.4 \%$ disagreed. People with a high school education or who completed some college were more likely to agree with this statement than those who attended graduate school, and rural residents were more likely to agree than urban residents. Our interpretation is that "control" is equated with "manage" and that a bare majority of the public in north-central Arizona expects continued human activity and intervention in Arizona forests.

\section{Discussion and Management Implications}

Our survey results show that northcentral Arizonans believe that forest fuel loads must be reduced. A majority view "restoration" as active management that includes more than fire risk reduction. In fact, $87.1 \%$ agreed that restoration means restoring "working ecosystems." Strong support for the idea that restoration should promote "working ecosystems," combined with strong support for the idea that restoration should recover rare and endangered species, suggests that most north-central Arizonans see restoration as restoring forest structure, function, and composition rather than as synonymous with fire risk reduction. Our survey results indicate that the public is divided, however, on issues such as whether appropriate restoration involves removing large trees or removing most trees both large and small. This highlights challenges faced by managers and practitioners in 
Table 3. Responses to survey questions on local perceptions of forest restoration in north-central Arizona. To define "the public," chi-square comparisons are reported on two demographic categories that revealed significant differences: highest education level achieved and urban vs. rural residence. "Highest education" compares respondents with a high school education to those with at least some college or graduate school experience. Strongly agree and agree were pooled together (SA/A), as were strongly disagree and disagree (SD/D). Respondents reported an average of 15.5 years of formal education completed $(n=673$, SD $=3.01)$. All percentages are within $5 \%$ with a confidence level of $95 \%$.

\begin{tabular}{|c|c|c|c|c|c|c|}
\hline \multirow{2}{*}{ Question (number of respondents) } & \multirow{2}{*}{ Response } & \multirow{2}{*}{$\%$} & \multicolumn{2}{|c|}{ Highest Education } & \multicolumn{2}{|c|}{ Urban vs. Rural } \\
\hline & & & $x^{2}$ & $p$-value & $x^{2}$ & $p$-value \\
\hline $\begin{array}{l}\text { I think forest restoration is important because I like forests } \\
(n=669) \text {. }\end{array}$ & $\begin{array}{l}\text { SA/A } \\
\text { Neutral } \\
\text { SD/D }\end{array}$ & $\begin{array}{r}81.3 \\
13.5 \\
5.2\end{array}$ & 23.52 & 0.005 & 2.21 & 0.529 \\
\hline $\begin{array}{l}\text { We should restore our forests because it is our duty to care } \\
\text { for the natural world }(n=680) \text {. }\end{array}$ & $\begin{array}{l}\text { SA/A } \\
\text { Neutral } \\
\text { SD/D }\end{array}$ & $\begin{array}{r}84.3 \\
11.6 \\
4.1\end{array}$ & 3.19 & 0.956 & 3.06 & 0.383 \\
\hline $\begin{array}{l}\text { The main purpose of restoration is to protect humans from } \\
\text { fire }(n=685) \text {. }\end{array}$ & $\begin{array}{l}\text { SA/A } \\
\text { Neutral } \\
\text { SD/D }\end{array}$ & $\begin{array}{l}31.7 \\
18.3 \\
50.1\end{array}$ & 20.13 & 0.017 & 10.97 & 0.012 \\
\hline $\begin{array}{l}\text { The main purpose of forest restoration should be to } \\
\text { promote working ecosystems }(n=675) \text {. }\end{array}$ & $\begin{array}{l}\text { SA/A } \\
\text { Neutral } \\
\text { SD/D }\end{array}$ & $\begin{array}{r}87.1 \\
7.3 \\
5.6\end{array}$ & 29.02 & 0.001 & 15.03 & 0.002 \\
\hline $\begin{array}{l}\text { Forest restoration efforts should be used to help recover } \\
\text { plant and animal species that are rare and endangered } \\
(n=681) \text {. }\end{array}$ & $\begin{array}{l}\text { SA/A } \\
\text { Neutral } \\
\text { SD/D }\end{array}$ & $\begin{array}{l}74.2 \\
12.0 \\
13.8\end{array}$ & 9.59 & 0.385 & 18.90 & 0.001 \\
\hline $\begin{array}{l}\text { I would support forest restoration even if most trees, large } \\
\text { and small, were removed }(n=683) \text {. }\end{array}$ & $\begin{array}{l}\text { SA/A } \\
\text { Neutral } \\
\text { SD/D }\end{array}$ & $\begin{array}{l}38.7 \\
13.0 \\
48.3\end{array}$ & 12.26 & 0.199 & 10.20 & 0.017 \\
\hline $\begin{array}{l}\text { Large trees should never be removed in restoration efforts } \\
(n=685)\end{array}$ & $\begin{array}{l}\text { SA/A } \\
\text { Neutral } \\
\text { SD/D }\end{array}$ & $\begin{array}{l}30.5 \\
14.3 \\
55.2\end{array}$ & 14.52 & 0.105 & 15.96 & 0.001 \\
\hline $\begin{array}{l}\text { For restoration, the forest may be thinned out by logging } \\
\text { but only once and then allowed to go wild }(n=686) \text {. }\end{array}$ & $\begin{array}{l}\text { SA/A } \\
\text { Neutral } \\
\text { SD/D }\end{array}$ & $\begin{array}{l}17.6 \\
20.9 \\
61.5\end{array}$ & 7.00 & 0.636 & 11.92 & 0.008 \\
\hline $\begin{array}{l}\text { We should allow natural areas to evolve as they will without } \\
\text { any intervention }(n=683) \text {. }\end{array}$ & $\begin{array}{l}\text { SA/A } \\
\text { Neutral } \\
\text { SD/D }\end{array}$ & $\begin{array}{l}34.6 \\
14.6 \\
50.8\end{array}$ & 20.73 & 0.014 & 4.84 & 0.184 \\
\hline Restoration efforts will help control nature $(n=676)$. & $\begin{array}{l}\text { SA/A } \\
\text { Neutral } \\
\text { SD/D }\end{array}$ & $\begin{array}{l}49.3 \\
22.3 \\
28.4\end{array}$ & 34.74 & 0.001 & 20.60 & 0.001 \\
\hline
\end{tabular}

implementing restoration projects that dramatically change the appearance of restored sites (see Friederici 2003).

Nearly a third $(31.7 \%)$ of respondents agreed that the purpose of restoration is to protect humans from fire, and nearly half agreed that restoration will help humans to control nature. This view is particularly strong among rural residents, who are likely to experience greater personal risks from forest fires. Rural residents are also more likely to support continued active management of the forest and the removal of large trees. Rural residents were less likely to agree that restoration should promote working ecosystems and less likely than urban residents to support restoration as a means to recover endangered species. But rural residents were also less likely to support the removal of most trees, suggesting a high value for the aesthetic quality of the forest. We infer that they are accustomed to relatively dense forest stands and thus may have difficulty perceiving a heavily thinned forest as a "healthy" forest. The fact that many respondents accept that restoration will change the appearance of the forest suggests that the USFS and organizations like the Ecological Research
Institute are successfully communicating the implications of restoration. However, this reference condition is not necessarily favored by those living within or near current forests.

Respondents with some college or graduate school education are less likely to support the concept that restoration will help us control nature (i.e., the biocentric notion that nature controls itself). This is consistent with other studies (Vaske et al. 2001), but those with higher levels of education were also less supportive of "allowing natural areas to evolve without human intervention." The apparent 
contradiction between believing that people cannot control nature with restoration, but should intervene in natural area evolution merits further investigation.

While over $60 \%$ believe that restoration involves thinning, prescribed burning, and either reintroducing/ preserving native species or eradicating invasives, $34.6 \%$ said that natural areas should be allowed to evolve "without any intervention." Furthermore, $16.4 \%$ of respondents selected "prescribed fire but no thinning" or "neither prescribed fire nor thinning," suggesting that they believe mechanical treatment is not part of restoration. These numbers are strong enough to indicate a significant portion of the public prefers to "let nature go wild." We believe further investigation would reveal that acceptance of letting nature manage itself depends on the state of the forest. This conclusion is consistent with Brunson and Shindler's (2004) study of opinions on fuel reduction in four western states, where large majorities supported active management to reduce fuels, but nearly half agreed that "following nature's way is preferable to human intervention in ecosystems." Likewise, Shindler et al. (2002) found that very small numbers of respondents believed letting nature "take its course" was appropriate in depleted or overstocked forest conditions, but up to $42 \%$ felt it was appropriate under "healthy" forest conditions. It is possible that respondents in the present study support "no intervention" as an option for currently healthy forests but would support active management of degraded forests. We encourage more research into public perceptions of the current state of forest health as well as social preferences for tradeoffs between maintaining dense forest conditions and the risk of catastrophic, stand-replacing wildfire.

Questions designed to measure the purpose of restoration and what may be the acceptable effects of restoration received neutral responses ranging from 12 to $22 \%$ (with the exception of the "working ecosystems" question). Our interpretation is that while a solid proportion of the public is aware of restoration and the actions of the USFS in north-central Arizona, more work can be done to communicate the intentions of the restoration community.

The findings here suggest that the public in north-central Arizona is diverse, but generally supports forest management that provides for more than just fuels reduction. In the end, however, we still must ask how much "good fire" can the public tolerate? Will the goal to restore ponderosa pine forests justify the five National Forests in Arizona producing smoke and flames on 20,000-48,000 hectares per year indefinitely? Our results indicate that public perceptions and opinion have shifted to include a basic understanding of restoration principles and goals. There is every reason to hope that we can continue the trend of public support to restore processes, function, and species composition across the Southwest.

\section{Acknowledgments}

This research was supported by a grant from the Ecological Restoration Institute, Northern Arizona University, Flagstaff, AZ 86011.

\section{References}

Abrams, J., E. Kelly, B.A. Shindler and J. Wilton. 2005. Value orientation and forest management: The forest health debate. Environmental Management 36:495-505.

Agee, J.K. 2002. The fallacy of passive management of western forest reserves. Conservation Biology in Practice 3(1):18-25.

Allen, C.D., D.A. Falk, M. Hoffman, J. Klingel, P. Morgan, M. Savage, T. Schulke, P. Stacey, K. Suckling and T.W. Swetnam. 2002. Ecological restoration of southwestern ponderosa pine ecosystems: A broad perspective. Ecological Applications 12:1418-1433.

Allison, S.K. 2004. What do we mean when we talk about ecological restoration? Ecological Restoration 22:281-286.

Arizona Daily Sun. 2001. The time is now to keep forests healthy. Editorial Page. August 10, 2001.
Bonnicksen, T.M. 1994. Social and political issues in ecological restoration. Pages 108-114 in W.W. Covington and L.F. DeBano (coords), Sustainable ecological systems: Implementing an ecological approach to land management. USDA Forest Service General Technical Report RM-27.

Brick, P., D. Snow and S. van de Wetering. 2001. Across the Great Divide: Explorations in Collaborative Conservation and the American West. Washington, DC: Island Press.

Bright, A.D., S.C. Barro and R.T. Burtz. 2002. Public attitudes toward ecological restoration in the Chicago metropolitan region. Society and Natural Resources 15:763-785.

Brunner, R.D., T.A. Stellman, L. CoeJuell, C.M. Cromley, C.M. Edwards and D.W. Tucker. 2005. Adaptive Governance: Integrating Science Policy and Decision Making. New York: Columbia University Press.

Brunson, M.W. and J. Evans. 2005. Badly burned?: Effects of an escaped prescribed burn on social acceptability of wildland fuels treatments. Journal of Forestry 103:134-138.

Brunson, M.W. and B.A. Shindler. 2004. Geographic variation in social acceptability of wildland fuels management in the western United States. Society and Natural Resources 17:661-678.

Brunson, M.W., B. Shindler and B.S. Steel. 1997. Consensus and dissension among rural and urban publics concerning forest management in the Pacific Northwest. Pages 83-94 in B.S. Steel (ed.), Public Lands Management in the West: Citizens, Interest Groups, and Values. Westport, CT: Greenwood Publishing.

Burns, S. 2003. Catron County, New Mexico: Mirroring the west, healing the land, rebuilding community. Pages 89-115 in J. Kusel and E. Adler (eds), Forest Communities, Community Forests. Lanham, MD: Rowman and Littlefield.

Connelly, N.A., T.L. Brown and D.J. Decker. 2003. Factors affecting response rates to natural resource-focused mail surveys: Empirical evidence of declining rates over time. Society and Natural Resources 16:541-549.

Cooper, C.F. 1960. Changes in vegetation, structure, and growth of southwestern pine forests since white settlement. Ecological Monographs 30:129-164.

Cortner, H.J., J.S. Vaughn and G.M.R. Teich. 2003. Designing a framework 
for evaluating the impacts and outcomes of Forest Service appeals. Summary of a workshop in Troutdale, OR, January 6-8, 2003. Flagstaff, AZ: Ecological Restoration Institute.

Covington, W.W. 2000. Prescribed fire is not the issue. Journal of Forestry 98(8):48. 2003a. The evolutionary and historical context. Pages 26-47 in P. Friederici (ed), Ecological Restoration of Southwestern Ponderosa Pine Forests. Washington, DC: Island Press.

2003b. Restoring ecosystem health in frequent-fire forests of the American West. Ecological Restoration 21:7-11.

Covington, W.W., R.L. Everett, R. Steele, L.L. Irwin, T.A. Daer and A.N.D. AuClair. 1994. Historical and anticipated changes in forest ecosystems of the inland west of the United States. Pages 13-63 in R.N. Sampson and D.L. Adams (eds.), Assessing Forest Ecosystem Health in the Inland West. New York: Food Products Press.

Dillman, D.A. 2000. Mail and Telephone Surveys: The Total Design Method, 2nd ed. New York: John Wiley and Sons.

Findley, A.J., M.S. Carroll and K.A. Blatner. 2001. Social complexity and the management of small-diameter stands. Journal of Forestry 99(12):18-27.

Friederici, P. 2003. The "Flagstaff Model." Pages 7-25 in P. Friederici (ed), Ecological Restoration of Southwestern Ponderosa Pine Forests. Washington, DC: Island Press.

2005. Restoration of ponderosa pine forests to presettlement conditions. Working Papers in Southwestern Ponderosa Pine Forest Restoration No. 9. Flagstaff: Ecological Restoration Institute, Northern Arizona University.

Ghioto, G. 2000. Forest thinning foiled again. Arizona Daily Sun 10/27/2000 on file at https://library.eri.nau.edu:8443/ bitstream/2019/91/1/Ghioto.2000. Forest ThinningFoiledAgain.pdf.

Gobster, P.H. and R. B. Hull (eds). 2000. Restoring Nature: Perspectives from the Social Sciences and Humanities. Washington, DC: Island Press.

Graber, D.M. 2003. Ecological restoration in wilderness: Natural versus wild in National Park Service wilderness. The George Wright Forum 20(3):34-41.

Gross, M. 2003. Inventing Nature: Ecological Restoration by Public Experiments. Lanham, MD: Lexington Books.

Healthy Forest Restoration Act (HFRA). 2003. U.S. Code 16 \$\$ 6501-6591.

Helford, R.M. 2000. Constructing nature as constructing science: Expertise, activist science, and public conflict in the Chicago wilderness. Pages 119-142 in P.H. Gobster and R.B. Hull (eds), Restoring Nature: Perspectives from the Social Sciences and Humanities. Washington, DC: Island Press.

Higgs, E.S. 1997. What is good ecological restoration? Conservation Biology 11:338-348.

Hobbs, R.J. and D.A. Norton. 1996. Towards a conceptual framework for restoration ecology. Restoration Ecology 4:93-110.

Jackson, L.L., N. Lopoukhine and D. Hillyard. 1995. Ecological restoration: A definition and comments. Restoration Ecology 3:71-75.

Jordan, W.R., III. 2000. Restoration, community, and wilderness. Pages 21-36 in P.H. Gobster and R. B. Hull (eds), Restoring Nature: Perspectives from the Social Sciences and Humanities. Washington, DC: Island Press.

Joyce, L.A. 2003. Improving the flow of scientific information across the interface of forest science and policy. Forest Policy and Economics 5:339-347.

Katz, E. 2000. Another look at restoration: Technology and artificial nature. Pages 37-48 in P.H. Gobster and R. B. Hull (eds), Restoring Nature: Perspectives from the Social Sciences and Humanities. Washington, DC: Island Press.

Kaufmann, M.R., P.Z. Fulé, W.H. Romme and K.C. Ryan. 2004. Restoration of ponderosa pine forests in the interior western U.S. after logging, grazing, and fire suppression. Pages 481-500 in J.A. Stanturf and P. Madsen (eds), Restoration of Boreal and Temperate Forests. Boca Raton, FL: CRC Press.

Loomis, J.B., L.S. Bair and A. GonzalezCaban. 2001. Prescribed fire and public support: Knowledge gained, attitudes changed in Florida. Journal of Forestry 99(11):18-22.

Manfredo, M.J., M. Fishbein, G.E. Haas and A.E. Watson. 1990. Attitudes toward prescribed fire policies: The public is widely divided in its support. Journal of Forestry 88(7):19-23.

Mast, J.N., P.Z. Fulé, M.M. Moore, W.W. Covington and A.E.M. Waltz. 1999. Restoration of presettlement age structure of an Arizona ponderosa pine forest. Ecological Applications 9:228-239.

Meadow, R., R.P. Reading, M. Phillips, M. Mehringer, B.J. Miller. 2005. The influence of persuasive arguments on public attitudes toward a proposed wolf restoration in the southern Rockies. Wildlife Society Bulletin 33:154-163.

Moore, M.M., W.W. Covington and P.Z. Fulé. 1999. Invited Feature - Reference conditions and ecological restoration: A southwestern ponderosa pine perspective. Ecological Applications 9:1266-1277.

Moore, M.M., D.W. Huffman, P. Z. Fulé, W.W. Covington and J.E. Crouse. 2004. Comparison of historical and contemporary forest structure and composition on permanent plots in southwestern ponderosa pine forests. Forest Science 50:162-176.

Moote, M.A. 2003. Community-based forest restoration. Pages 335-352 in P. Friederici (ed), Ecological Restoration of Southwestern Ponderosa Pine Forests. Washington, DC: Island Press.

National Fire Plan 2001. Review and Update of the 1995 Federal Wildland Fire Management Policy. http://www. forestsandrangelands.gov/NFP/index. shtml.

Noss, R.F., P. Beier, W.W. Covington, R.E. Grumbine, D.B. Lindenmayer, J.W. Prather, F. Schmiegelow, T.D. Sisk and D.J. Vosick. 2006. Recommendations for integrating restoration ecology and conservation biology in ponderosa pine forests of the southwestern United States. Restoration Ecology 14:4-10.

Ostergren, D.M., K.A. Lowe, J.B. Abrams and E.J. Ruther 2006. Public perceptions of forest management in north-central Arizona: The paradox of demanding more involvement but allowing limits to legal action. Journal of Forestry 104:375-382.

Pyne, S.J. 2004. Tending Fire: Coping with America's Wildland Fires. Washington, DC: Island Press.

Schumman, M. 2004. Fuel reduction projects in southwest ponderosa pine forests: A description of sites and treatments. National Community Forestry Center, Southwest Region Working Paper No. 9. Santa Fe, NM: Forest Guild.

Shelby, B. and R.W. Speaker. 1990. Public attitudes and perceptions about prescribed burning. Pages 253-260 in J.D. Walstad, S.R. Radosevich and D.V. Sandberg (eds), Natural and Prescribed Fire in Pacific Northwest Forests, Corvallis: Oregon State University Press.

Shindler, B.A., P. List and B.S. Steel. 1993. Managing federal forests: Public attitudes in Oregon and nationwide. Journal of Forestry 91(7):36-42.

Shindler, B.A., J. Wilton and A. Wright. 2002. A Social Assessment of Ecosystem 
Health: Public Perspectives on Pacific Northwest Forests. Corvallis: Department of Forest Resources, Oregon State University.

Simpson, T.B. 2005. Ecological restoration and re-understanding ecological time. Ecological Restoration 23:46-51.

Sisk, T.D., J.W. Prather, H.M. Hampton, E.N. Aumack, Y. Xu and B.G. Dickson 2006. Participatory landscape analysis to guide restoration of ponderosa pine ecosystems in the American Southwest. Landscape and Urban Planning. 78:300-310.

Solop, F.I., K.K. Hagen and D. M. Ostergren. 2004. Managing nonnative plants and animals: Analysis of public opinion. National Park Service Technical Report to the Department of Interior. http:// www.nature.nps.gov/socialscience/pdf/ Managing_Nonnative_Plants_and_ Animals_Report_07_2004.pdf.

Taylor, J.G. and T.C. Daniel. 1984. Prescribed fire: Public education and perception. Journal of Forestry 82:361-365.

Theodori, G.L. and A.E. Luloff. 2002. Position on environmental issues and engagement in proenvironmental behaviors. Society and Natural Resources 15: 471-482.

Thomas, J.W. 2002. Dynamic vs. static management in a fire-influenced landscape: The Northwest Forest Plan. Paper presented at the Fire in Oregon's Forests conference, Bend, OR, October 23, 2002.

Toman, E. and B.A. Shindler. 2003. Hazardous fuel reduction in the Blue Mountains: Public attitudes and opinions. Pages 241-254 in P.N. Omi and L.A. Joyce (eds), Fire, Fuel Treatments, and Ecological Restoration, USDA Forest Service RMRS-P-29.
U.S. Department of Agriculture and Department of the Interior (USDA/ DOI). 2000. Managing the impact of wildfires on communities and the environment. A report to the President in response to the wildfires of 2000 . http://www.fs.fed.us/emc/hfi/president. pdf.

U.S. Forest Service (USFS) 2000 Decision Notice and Finding of No Significant Impact (FONSI) Fort Valley Ecosystem Restoration Project. http://www.fs.fed.us/r3/coconino/nepa/ fort_valley_dn.html.

Vaske, J.J., M.P. Donnelly, D.R. Williams and S. Jonker. 2001. Demographic influences on environmental value orientations and normative beliefs about national forest management. Society and Natural Resources 14:761-776.

Vining, J., E. Tyler and B. Kweon. 2000. Public values, opinions, and emotions in restoration controversies. Pages 143-161 in P.H. Gobster and R.B. Hull (eds), Restoring Nature: Perspectives from the Social Sciences and Humanities. Washington, DC: Island Press.

Vogt, C. 2003. Seasonal and permanent home owners' past experiences and approval of fuels reduction. Pages 63-73 in Homeowners, communities, and wildfire: Science findings from the National Fire Plan. USDA Forest Service General Technical Report NC-231.

Vogt, C., G. Winter and J.S. Fried. 2003. Antecedents to attitudes toward prescribed burning, mechanical thinning, and defensible space fuel reduction techniques. Pages 74-83 in Homeowners, communities, and wildfire: Science findings from the National Fire Plan. USDA Forest Service General Technical Report NC-231.
Winter, G.J. and J.S. Fried. 2000. Homeowner perspectives on fire hazard, responsibility, and management strategies at the wildland-urban interface. Society and Natural Resources 13:33-49.

Winter, G.J., C.A. Vogt and J.S. Fried. 2002. Fuel treatments at the wildlandurban interface: Common concerns in diverse regions. Journal of Forestry 100(1):15-21.

Winter, G.J., C.A. Vogt and S. McCaffrey. 2004. Examining social trust in fuels management strategies. Journal of Forestry 102(6):8-15.

Winter, P.L. and Cvetkovich, G.T. 2003. A study of Southwesterners' opinions on the management of wildland and wilderness fires: Fire management version. Riverside, CA: Wildland Recreation and Urban Cultures, Pacific Southwest Research Station, USDA Forest Service.

Woolley, J.T. and M.V. McGinnis. 2000. The conflicting discourses of restoration. Society and Natural Resources 13:339-357.

David M. Ostergren, Ph.D., Box 15018, School of Forestry, Northern Arizona University, Flagstaff, AZ 86011 , 928/523-0701, david.ostergren@nau.edu

Jesse B. Abrams, Box 15018, Ecological Restoration Institute, Northern Arizona University, Flagstaff, AZ 86011

Kimberly A. Lowe, Box 15018, Ecological Restoration Institute, Northern Arizona University, Flagstaff, AZ 86011 